\title{
SCALIA, HAMDAN AND THE PRINCIPLES OF SUBJECT MATTER RECUSAL
}

\section{Brian Flanagan *}

The point of judicial recusal is at once obvious and elusive. The idea of a partial judge immediately grates on our sense of fairness. Almost invariably, the normative basis of judicial impartiality is traced to what is described as 'natural justice'; ${ }^{1}$ specifically the celebrated maxims of nemo iudex in causa sua $^{2}$ and audi alteram partem. ${ }^{3}$ But the relationship of this moral bedrock to the exigencies and settled practices of constitutional adjudication is far from straightforward. This article will focus on the implications of the latter principle - perhaps best translated as a standard of judicial open-mindedness regarding the subject matter of a dispute. Despite its moral immediacy, there are serious theoretical objections, best described as 'realist,' to an expansive conception of judicial open-mindedness. Likewise, at a practical level, the institution of the dissenting opinion can be seen as diluting the duty to keep an open mind, at least in jurisdictions such as the US where judges are expected to exhibit relatively little deference towards previous decisions in which they were outvoted.

The issue of judicial impartiality was placed in sharp relief by the recent controversy surrounding US Supreme Court Justice Antonin Scalia's extrajudicial commentary on legal questions relating to a then pending Supreme Court case, Hamdan v Rumsfeld. ${ }^{4}$ In Part I, the article will proceed with a doctrinal analysis of the legality of Justice Scalia's decision to sit in the

\footnotetext{
* Balliol College, Oxford. I assisted in the preparation of Binyam Mohamed's amicus curiae brief to the Supreme Court in support of the Petitioner in the Hamdan case. The brief related solely to the merits of the petition. I am grateful to Ravinder Thukral, Greg Ó Ceallaigh and the Denning reviewers for their helpful comments on earlier drafts of this paper, and to David Whelan for directing me to some interesting case law. The usual disclaimer applies.

${ }^{1}$ As in the Scottish case of Bradford v McLeod [1986] SLT 244 where the Court, in grounding its standard of judicial impartiality, declared it was 'entirely satisfied that what are commonly referred to as the rules of natural justice apply to criminal trials in this country.' at 247. See also the Commonwealth case of Kanda v Government of Malaya [1962] AC 322 at 337, '[t]hose two rules [the rule against bias and the right to be heard] are the essential characteristics of what is often called natural justice' (Denning LJ).

2 That no one be a judge in their own case.

3 That one must listen to both sides.

${ }^{4}$ Supreme Court Docket No. 05-184; 126 S Ct 2749 (2006).
} 
case notwithstanding his prior remarks. Taking a broader perspective, Part II will consider whether objections to Justice Scalia's participation in Hamdan can be reconciled with the nature of appellate adjudication and, in relation to dissenting opinions, with an established feature of adjudicative practice in most common law jurisdictions.

\section{PART I: HAMDAN AND THE LAW OF RECUSAL}

\section{Section A: Swiss Judicial Neutrality}

During a Q\&A session on March $8^{\text {th }}$ of last year at the University of Freiburg in Switzerland, Justice Scalia noted his astonishment at "the world reaction to Guantanamo," and declared that "[w]ar is war, and it has never been the case that when you capture a combatant you have to give them a jury trial in your civil courts." ${ }^{5}$ Challenged as to the justice of incarcerating an individual in Guantanamo Bay without having proven their guilt, Scalia interjected, "If he was captured by my army on a battlefield, that is where he belongs. I had a son on that battlefield and they were shooting at my son and I'm not about to give this man who was captured in a war a full jury trial. I mean it's crazy." When the questioner suggested a role for the Geneva Conventions in the matter, Scalia asked "What do they mean?" and answered, "They mean almost anything."

It is difficult to imagine Justice Scalia being oblivious to the Hamdan case $^{6}$ when making these remarks. ${ }^{7}$ Oral argument in the Supreme Court was

5 A video of the Justice's speech is available at http://bafweb.com/index.php?s=scalia
6 Hamdan's facts, as had been found by the Court of Appeal (DC Circuit), were that Afghani militia forces captured the petitioner in Afghanistan in late November 2001. His captors turned him over to the American military, which transported him to the Guantanamo Bay Naval Base in Cuba. The military initially kept him in the general detention facility, known as Camp Delta. On July 3, 2003, the President determined 'that there is reason to believe that [Hamdan] was a member of al Qaeda or was otherwise involved in terrorism directed against the United States.' Hamdan was designated for trial before a military commission. In April 2004, Hamdan filed a petition for habeas corpus. While his petition was pending before the district court, the government formally charged Hamdan with conspiracy to commit attacks on civilians and civilian objects, murder and destruction of property by an unprivileged belligerent, and terrorism. In response to the Supreme Court's decision in Hamdiv Rumsfeld 124 S Ct 2633 (2004), Hamdan received a formal hearing before a Combatant Status Review Tribunal. The tribunal affirmed his status as an enemy combatant for whom continued detention was required. On November 8, 2004, the district court granted in part Hamdan's petition. Among other things, the court held that Hamdan could not be tried by a military commission unless a competent tribunal determined that he was not a prisoner of war under the 1949 Geneva Convention 
less than three weeks away and it was clear to any informed observer that the case had the potential to have enormous implications for the Bush Administration's approach to bringing its Guantanamo captives to justice. ${ }^{8}$ In response to Justice Scalia's comments, a request for his recusal was filed on March 27 by one of Hamdan's amici curiae, 'Retired Generals'. 9 Ignoring this request, Justice Scalia proceeded to take part in oral argument ${ }^{10}$ and subsequently dissented from the Court's reversal of the Court of Appeals' decision to deny Hamdan relief. ${ }^{11}$

governing the treatment of prisoners. The court therefore enjoined the Secretary of Defense from conducting any further military commission proceedings against Hamdan. The district court's decision was reversed by the court of appeal on July 15, 2005. The questions for which Hamdan was granted certiorari by the Supreme Court were: 1. Whether the military commission established by the President to try petitioner and others similarly situated for alleged war crimes in the 'war on terror' is duly authorized under Congress's Authorization for the Use of Military Force (AUMF); the Uniform Code of Military Justice (UCMJ); or the inherent powers of the President? 2. Whether petitioner and others similarly situated can obtain judicial enforcement from an Article III court of rights protected under the 1949 Geneva Convention in an action for a writ of habeas corpus challenging the legality of their detention by the Executive branch?

${ }^{7}$ For instance, in an essay by Adam Cohen published in the New York Times on April 3, 2006 (which did not refer to any recusal issue) Hamdan was described as 'probably the term's most important case.' The following day, the paper's editorial board described the case as 'momentous'. On March 28, the Washington Post described Hamdan as 'one of the most important terrorism-related cases to reach the court.' Likewise, on February 7, Hamdan received prominent mention in a speech on comparative law by Justice Scalia's colleague, Justice Ginsburg. Hamdan was the only case on the Supreme Court docket referred to by Ginsburg. Indeed according to the Philadelphia Inquirer editorial of March 31, Justice Scalia himself told his Freiburg audience that he was "only weeks away from sitting in judgment on Osama's former wheelman."

${ }^{8}$ Evidence of Hamdan's importance could be found in the number of its amici curiae - a total of 53 briefs were filed.

${ }^{9}$ The amicus' letter is viewable at http://www.scotusblog.com/movabletype/archives/HamdanRecusalLetter.pdf ${ }^{10}$ The case was argued on March 28.

${ }^{11}$ Justice Scalia's dissenting opinion dealt solely with the question of whether the Court had jurisdiction to hear Hamdan's petition, and concluded that it did not. The argument might thus be made that any prejudicial view which the Justice may have entertained regarding the substance of Hamdan's petition would ultimately have been irrelevant to his disposition of the case. One sufficient reason for considering this argument unsustainable, however, is Justice Scalia's joining of Justice Thomas' dissenting opinion. The Thomas dissent dealt in detail with the substance of each of the questions for which the Court had granted Hamdan certiorari. 


\section{SCALIA, HAMDAN AND THE PRINCIPLES OF SUBJECT MATTER RECUSAL}

The federal law regulating Justice Scalia's participation in Hamdan provides, in relevant part, that:

(a) Any justice, judge, or magistrate judge of the United States shall disqualify himself in any proceeding in which his impartiality might reasonably be questioned.

(b) He shall also disqualify himself in the following circumstances:

(5) He or his spouse, or a person within the third degree of relationship to either of them ...:

(iii) Is known by the judge to have an interest that could be substantially affected by the outcome of the proceeding; ${ }^{12}$

There were two potential grounds for Justice Scalia's recusal. The first was that the Justice had formed his opinion on the merits of Hamdan's petition prior to hearing Hamdan's arguments thereon and was thus unfit to decide the case due to prejudice. The second had been his perception that his son was maliciously injured or endangered by battlefield detainees. Justice Scalia's remarks indicate he viewed this endangerment as relevant to the legality of a battlefield detainee's treatment. Thus it could be argued that "a person [within the first degree of relationship] was known by the judge to have an interest [in seeing his enemies held captive and/or brought to justice] that could have been substantially affected by the outcome of the proceeding," $" 13$ to wit, whether battlefield detainee Hamdan could be tried under President Bush's military commissions, as then constituted. The first ground relates to the prejudgment of the substance of a case and is addressed by subsection (a); the second ground concerns personal interest bias and is dealt with by both (a) and (b)(5)(iii). This article will focus on the first ground only.

\section{Section B: Subject Matter Prejudice}

Writing for the Supreme Court in one of its few opinions on subsection (a), Justice Scalia held that:

[I]t was an entirely new 'catch-all' recusal provision, covering both 'interest or relationship' and 'bias or prejudice' ... but requiring them all to be evaluated on an objective basis, so that what matters is not the reality of bias or

\footnotetext{
${ }^{12}$ Section 455 of Title 28, Part I, Chapter 21 of the US Code.

${ }^{13}$ Per Section 455 (b)(5).
} 
prejudice, but its appearance. Quite simply and quite universally, recusal was required whenever 'impartiality might reasonably be questioned. 14

As regards the question of subject matter prejudice, the history of the enactment of Section 455 happened to shed some light on Justice Scalia's situation. The subject of recusal had arisen in the Supreme Court's 1972 decision in Laird $v$ Tatum. ${ }^{15}$ Laird involved a constitutional challenge to the Army's surveillance of civilian political activity. While serving in the Department of Justice prior to his elevation to the Supreme Court, William Rehnquist had commented on the proper application of the law to the facts of the Laird case, which was then pending in a lower court. ${ }^{16}$ The recusal issue in Laird was whether Rehnquist, having already articulated his views on the merits of the case, was prejudiced towards the Supreme Court arguments of one of its parties. Rehnquist's subsequent decision to sit in the case and provide the crucial fifth vote for the Army's surveillance activities provoked controversy. In response, the American Bar Association adopted a new cannon that required a judge to recuse himself whenever "his impartiality might reasonably be questioned." 17 In 1974, taking the cannon as its model, Congress enacted Section 455 with the stated goal of "promoting confidence in the impartiality of the judicial system." 18 It seems clear, therefore, that Section 455 (a) was enacted to prohibit Laird style non-recusals. ${ }^{19}$

\footnotetext{
${ }^{14}$ Liteky $v$ US 510 US 540 (1994) at 548.

${ }^{15} 408$ US 1 (1972).
}

${ }^{16}$ Hearings before the Subcommittee on Constitutional Rights of the Committee on the Judiciary of the United States Senate, 92nd Cong, 1st Session, on "Federal Data Banks, Computers and the Bill of Rights,', Part I, at 864-5 (1971).

${ }^{17}$ Cannon 3C (now Cannon 3E).

${ }^{18}$ HR REP NO 93-1453 (1974) at 2, 5. This goal and the Congressional intention to conform with Cannon 3C was noted by the Supreme Court in Liljeberg $v$ Health Services Acquisition Corp., 486 US 847 (1988) fn 7. See further A Frost, 'Keeping Up Appearances: A Process-Oriented Approach to Judicial Recusal' 53 Kansas L Rev 531, 545-547 (2005) and C L Roberts, 'The Fox Guarding the Henhouse?: Recusal and the Procedural Void in the Court of Last Resort' 57 Rutgers Law Review 107, 138-143 (2004).

${ }^{19}$ Interestingly, when questioned on his decision not to recuse in Laird during his Senate confirmation hearings for the position of Chief Justice, Rehnquist remarked, "I have gone back and read the opinion, and I think, under the statute as it was changed after Laird v Tatum, I think there would be probably a very strong ground for [my] disqualification. But I didn't feel dissatisfied with the way I had behaved under the statute as it then stood.' S Hrg 99-1067, p 184. 


\section{SCALIA, HAMDAN AND THE PRINCIPLES OF SUBJECT MATTER RECUSAL}

One difference between Laird and Hamdan suggests itself. In his pre-case remarks, Rehnquist referred to Laird by name; whereas Justice Scalia did not mention Hamdan. The difference lay in Justice Scalia's favour, but was arguably insufficient to meet the post Laird standard of judicial impartiality introduced by Section 455. To maintain that Scalia was any less partial towards Rumsfeld than Rehnquist was towards Laird, one must assume Scalia had not adverted his mind to Hamdan's Supreme Court petition prior to holding forth on its subject matter. Given the petition's imminence and notoriety, this scenario appears implausible, especially in light of the remarkable perspicuity the Justice had demonstrated earlier in his Swiss remarks regarding a different 'case.' Asked about the constitutionality of restrictive abortion legislation that had recently been enacted by South Dakota ${ }^{20}$ but which at that time was not even the subject of a lawsuit, Justice Scalia refused to answer. Looking directly into the camera, the Justice noted that the case might wend its way up to the Supreme Court someday and that it would thus be inappropriate for him to pronounce upon it. ${ }^{21}$

The Supreme Court has not elaborated a specific test for subject matter prejudice or bias under Section 455, but guidance can be drawn from its comments in Liteky regarding an 'objective basis' and its dictum in Liljeberg $v$ Health Services Acquisition Corp. that "[t]he goal of section 455(a) is to avoid even the appearance of partiality." 22 This would suggest the appropriate test is whether there exists a reasonable apprehension of partiality. ${ }^{23}$ Let us therefore take the perspective of the reasonable man. If he felt that Justice Scalia had simply been noting the historical precedent for the Executive's proposals - rather than commenting on what rights a detainee should enjoy at trial - a reasonable observer might not have entertained doubts as to the Justice's impartiality. Were historical standards to mean little

${ }^{20}$ Signed into law by Governor Mike Rounds on March 6, 2006.

${ }^{21}$ See $\mathrm{n} 5$. The legislation in question was subsequently repealed by statewide referendum on November 7, 2006, without having been tested in federal court.

${ }^{22} 486$ US 847, 860 (1988).

${ }^{23}$ That the objective appearance of partiality is sufficient to warrant judicial recusal is likewise the position prevailing in several other common law jurisdictions. See for instance Bradford v McLeod (n 1) at 247 (Scotland); Locabail (UK) Ltd v Bayfield Properties Ltd [2000] HRLR 290 at 301, 314 (England and Wales) - cited approvingly in the Privy Council case of Diedrichs-Shurland $v$ Talanga-Stiftung [2006] UKPC 58 paras 22-23; Bula Limited v Tara Mines Limited (No 6) [2000] 4 I.R. 412, 449 (Ireland); Ebner v Official Trustee in Bankruptcy (2000) 205 CLR 337 para 6 (Australia); Wewaykum Indian Band v Canada [2003] 2 SCR 259, para 60 (Canada); Auckland Casino Ltd. v Casino Control Authority [1995] 1 NZLR 142, 149 (New Zealand); President of South Africa v South African Rugby Union Football (1999) (4) SA 149 paras 35-39. See also Langborger v Sweden (1990) 12 EHRR 416, paras 32, 35 (European Court of Human Rights). 
to Justice Scalia, that hypothesis might stand. However, it is exceptionally rare for Justice Scalia to make an historical observation while discussing the constitutionality of a legal practice without employing that observation in the latter's favour or vice versa. As he made clear during his Swiss remarks, Justice Scalia is a committed originalist for whom statements such as 'it has never been the case that when you capture a combatant you have to give them a jury trial in your civil courts' could only ever function as a reason to deny such a trial. ${ }^{24}$ An objective observer would thus remain concerned that the Justice had already applied his theory of constitutional interpretation to the case at bar.

Quite apart from Title 28, Justice Scalia's conduct may raise constitutional questions. In Re Murchison, ${ }^{25}$ the Supreme Court made an arguably analogous recusal decision based on the due process clause ${ }^{26}$ of the Fourteenth Amendment. The issue was whether a contempt proceeding complied with the due process requirements of an impartial tribunal where the judge presiding at the contempt hearing had also served as the 'one-man grand jury' out of which the contempt charges arose. The Court held that:

"[i]t would be very strange if our system of law permitted a judge to act as a grand jury and then try the very persons accused as a result of his investigations. . . Having been a part of that process a judge cannot be, in the very nature of things, wholly disinterested in the conviction or acquittal of those accused. While he would not likely have all the zeal of a prosecutor, it can certainly not be said that he would have none of that zeal.",27

It is not entirely clear whether the prejudice found in Murchison was that the judge had become emotionally committed to having his own decision to prefer charges vindicated as a matter of professional pride at the subsequent hearing or whether it lay in the judge bearing a disposition on the merits prior

${ }^{24}$ Justice Scalia has articulated his judicial philosophy in many public fora over the years. One could go so far as to credit the Justice with putting 'originalism' on the international legal map. For an authoritative treatment see his 'A Matter of Interpretation: Federal Courts and the Law' (New Jersey; Princeton University Press 1997).

${ }^{25} 349$ US 133 (1955).

${ }^{26}$ US Constitution, Fourteenth Amendment, Section 1, "No State shall make or enforce any law which shall abridge the privileges or immunities of citizens of the United States; nor shall any State deprive any person of life, liberty, or property, without due process of law; nor deny to any person within its jurisdiction the equal protection of the laws."

${ }^{27}$ At 137 . 


\section{SCALIA, HAMDAN AND THE PRINCIPLES OF SUBJECT MATTER RECUSAL}

to the hearing which would inevitably cloud his judgment thereof. In the latter case, the Fourteenth Amendment was held to constitutionally enshrine a principle of judicial open-mindedness. As such, Justice Scalia's substantive comments on Hamdan's position would place his judicial qualification to hear the latter's petition under considerable pressure. In the former case, Murchison could only be read as taking a strong line against the appearance in the judiciary of emotional commitment to a particular outcome, "prosecutorial zeal.' But such a reading would have equally negative implications for a Justice's decision to sit where he views one of the litigants as partially responsible for the malicious endangerment of his own son; endangerment he considers relevant to the issue of law at bar. Thus on either construction of Murchison's legal standard (or on a mélange of both), the Freiburg event implicated the question of recusal. Moreover, the test applied to the due process clause by Murchison was as rigorous as that imputed by Liteky and Liljeberg to Section 455 (a), "our system of law has always endeavored to prevent even the probability of unfairness ... to perform its high function in the best way justice must satisfy the appearance of justice." 28

On the analysis thus far, federal law appears to dictate recusal for prejudice as the appropriate course for Justice Scalia in Hamdan. As it stands, however, that conclusion is not incontrovertible. Likewise, we have yet to address a primary objection to the whole notion of judicial recusal - that judges are bound to have preconceived ideas about the law before they go into a case, many of which have been cogently expressed in their prior dissents. Fortunately, we are in a position to garner some guidance on these questions from Justice Scalia's own record regarding the norms of subject matter prejudice.

\section{Section C: Justice Scalia's Standards}

On January 12 2003, Scalia spoke in Fredericksburg, Virginia at an event sponsored by the Knights of Columbus. Remarking generally on the trend of the Supreme Court's jurisprudence under the Establishment Clause, he criticised a decision of the Ninth Circuit on the wording of the Pledge of Allegiance. ${ }^{29}$ At the time he spoke, the Newdow case had been decided by a three-judge Ninth Circuit court of appeal panel, and was being considered for en banc rehearing. On February 28, rehearing was denied. On April 30, the school district that lost the Newdow case filed for review by the Supreme Court, and on October 14 the Court granted review of the case. It was argued

\footnotetext{
${ }^{28}$ At 136.

${ }^{29}$ See for instance the report of The Free Lance-Star at http://fredericksburg.com/News/FLS/911/2003/012003/01132003/846367
} 
before the Supreme Court on March 24 2004. Without comment, Justice Scalia recused himself from consideration of Newdow. ${ }^{30}$ In his memo explaining his refusal to disqualify himself from the Cheney case, he stated:

\begin{abstract}
"Recusal is the course I must take - and will take - when, on the basis of established principles and practices, I have said or done something which requires that course. I have recused for such a reason this very Term. See Elk Grove Unified School District v Newdow. "31
\end{abstract}

In substance, there does not appear to be any difference between Justice Scalia's comments in relation to Newdow and his comments with regard to Hamdan. Indeed, whereas Hamdan was on the Justice's docket and only weeks from oral argument when he spoke in Freiburg, at the time of his comments in Fredericksburg, Newdow remained ten months from a Supreme Court decision. Moreover, at that point, Newdow had not even worked its way out of the Court of Appeal and petition for certiorari would not be filed for a further 3 and half months. It is true that Justice Scalia did not refer to Hamdan by name in Freiburg whereas he appears to have mentioned the Ninth Circuit's decision in Fredericksburg. But as with the Laird analogy, it is difficult to believe the Justice was not adverting to the Hamdan case in making his comments, despite omitting to mention it by name.

Consider the following extrajudicial response to a question asking whether different standards of judicial review should be applied under the equal protection clause of the Fourteenth Amendment:

"I just cannot do it [answer], and, I think the only way to be sure that I am not impairing my ability to be impartial, and to be regarded as impartial in future cases before the Court, is simply to respectfully decline to give an opinion on whether any of the existing law on the Supreme Court is right, or wrong."

When asked if the views expressed in a legal article he wrote four years before reflected his current views:

"I do not think I should say. As far as a litigant who has to appear before me is concerned, it is troublesome enough to

\footnotetext{
${ }^{30}$ Elk Grove Unified School District v Newdow 542 US 1.

${ }^{31}$ Cheney $v$ US District Court 541 US (2004) Memorandum of Scalia J. For an outline of the controversy regarding Justice Scalia's qualification to sit in Cheney given his friendship with the Vice President see Frost (n 18) at 572-76.
} 


\section{SCALIA, HAMDAN AND THE PRINCIPLES OF SUBJECT MATTER RECUSAL}

them, I suppose, that I once wrote views on one side or another like that, to reaffirm them after I am a sitting judge."

When questioned if Marbury $v$ Madison $^{32}$ was correctly decided:

"I do not want to say that anything is a settled issue as far as I am concerned. If somebody wants to come in and challenge Marbury $v$ Madison, I will listen to that person. . . I really do not want to say with respect to any decision that I would not listen to a litigant who wants to challenge it."

A more uncompromising defence of judicial open-mindedness regarding the substance of future litigation would be hard to find. The defence is that of Judge Antonin Scalia given in sworn testimony before the Senate Committee on the Judiciary prior to his confirmation as Associate Justice of the US Supreme Court. ${ }^{33}$ A federal judge who is wary of making extrajudicial pronouncements on Madison $v$ Marbury for fear of prejudicing an unidentifiable future litigant would surely baulk at the prospect of deciding an identifiable litigant's fate having publicly dispatched the relevant legal question before hearing the litigant's argument. Of course, refusing to answer senatorial questions on the merits of any specific point of law (especially the most settled ones) enabled Judge Scalia to give a principled reason for declining to say where he stood on several hot button issues, most notably Roe $v$ Wade. $^{34}$ Indeed the fact that so many Senators accepted an appeal to judicial open-mindedness as reason enough for a judge to refuse to answer their questions suggests that the principle has considerable traction. ${ }^{35}$ In any

\footnotetext{
325 US 137 (1803).
}

33 S Hrg 99-1064 (August $5^{\text {th }} 1986$ ). The quotes can be found at p 58, 59 and 83 respectively.

34410 US 113 (1973).

35 Justice Scalia was confirmed by a vote of 98-0. During the hearings, when asked by Senator Edward Kennedy (amongst several others) whether he would overrule Roe $v$ Wade, Scalia declined to answer. At this point, the Chairman of the Judiciary Committee, Senator Strom Thurmond, intervened in support of the judge, stating at $p$ 37, 'I agree with you. I do not think it is proper to ask any question that he has to act on or may have to act on.' Similarly, several members of the Judiciary Committee referred to the principle of judicial open-mindedness (in substance if not by name) in their official statements on Judge Scalia's nomination. See Thurmond at p 2, 'a person who is open-minded;' Hatch at p 15 'his openness to varied viewpoints,' and 'judicial temperament;' Denton at p 23, 'a judge who eagerly seeks out the opinions and viewpoint of his fellow judges when he is formulating a position;' DeConcini at $\mathrm{p}$ 17, 'judicial temperament;' McConnell at 29, 'judicial temperament;' Leahy at p 20, 
case, on the question of subject matter prejudice, both federal law and Justice Scalia's own articulated standards suggest that, in Hamdan, recusal would have been the more appropriate course. ${ }^{36}$

The advisability of a Scalia recusal is confirmed by a clear line of federal Court of Appeals precedent to the effect that, where the "question of whether $\S 455$ (a) requires disqualification is a close one, the balance tips in favor of recusal." ${ }^{, 37}$ Moreover, as Chief Justice Roberts had already recused himself from the case, ${ }^{38}$ the commonly raised spectre of an equally divided court passively affirming the decision below could not apply in Hamdan. ${ }^{39}$ In relation to his Swiss remarks, the prospect of a 4-4 decision arose only by

'Your philosophy about the standards you would apply in recusing yourself from cases.'

${ }^{36}$ Note I am not attempting to draw a parallel between the importance of a Justice's testimony at his Supreme Court confirmation hearing and the lectures he may deliver at university settings. Equally, I offer no view at this point as to whether Justice Scalia would have prejudiced himself had he answered questions concerning the correct state of the law at his confirmation hearings. The point is simply to draw attention to the nature of the standards which Justice Scalia had himself proposed regarding the principle of judicial open-mindedness.

${ }^{37}$ Patterson v Mobil Oil Corp 335 F3d 476 CA 5 (Tex) 2003 at 484; In re Chevron USA., Inc 121 F.3d 163 CA 5 (Tex) 1997 at 165; Nichols v Alley 71 F3d 347 CA 10 (Okl) 1995 at 352; US v Dandy 998 F2d 1344 CA 6 (Mich) 1993 at 1349; In re Boston's Children First 244 F.3d 164 CA 1, 2001 at 167; Republic of Panama v American Tobacco Co Inc 217 F3d 343 CA 5 (La) 2000 at 347. This 'tie-breaker' consideration is also applicable in other common law jurisdictions, see for instance Locabail (n 23) at 304, 'if in any case there is real ground for doubt, that doubt should be resolved in favour of recusal' (England and Wales).

${ }^{38}$ Having participated in the Court of Appeal decision for which petitioner Hamdan had been granted certiorari by the Supreme Court.

${ }^{39}$ Cheney v US District Court 541 US (2004) Memorandum of Scalia J at II; Laird v Tatum 409 US 824 (1972) Memorandum of Rehnquist J at 837; Microsoft Corp v US 121 S Ct 25 (2000) Memorandum of Rehnquist CJ at 27. (The memoranda set out the respective Justices' reasons for not considering themselves disqualified from sitting on the cases in question.) See also Justice Ginsburg's comment to this effect in 'An Open Discussion with Justice Ruth Bader Ginsburg' 36 Conn L Rev 1033, 1038 (2004). According to Supreme Court practice, an equally divided court has the effect of affirming the decision under review without producing any precedential impact; see Eaton v Price 364 US 263 (1960). However, recent empirical work by Lee Epstein and Ryan Black suggests that the fear of equal division on the Supreme Court is largely unfounded. 'Recusals and the "Problem" of an Equally Divided Supreme Court' 7 J Appellate Prac \& Process 75 (2005) (finding that between the 1946 and 2003 terms less than ten percent of impartiality recusals resulted in an equal division on the subsequent decision). 
virtue of Justice Scalia's decision to hear the case despite his apparent conclusions as to its merits.

But whatever the doctrinal position regarding disqualification in this instance, broader concerns as to the plausibility of insisting on recusal for subject matter prejudice present themselves: is a subject matter dimension to the principle of audi alteram partem practical, or even coherent?

\section{PART II: THE LAW OF RECUSAL AND THE ADMINISTRATION OF JUSTICE}

\section{Section A: The 'Realist' Objection}

There remains a cogent 'realist' objection to our subject matter analysis thus far, namely, that since judges will inevitably have fixed ideas about the law, penalising them for expressing those ideas off the bench, especially when they have already said as much in previous dissents, is arbitrary and nonsensical. The principle of judicial open-mindedness is thus an illusion. To understand the limits of this point we need to consider the normative basis of subject matter impartiality and how it relates to the process of constitutional adjudication.

Any legal system which takes positions on questions of morality or politics will necessarily place some of its litigants at a disadvantage. Simply put, certain actors will find their activities closer to the right side of the law than others. ${ }^{40}$ Moreover, as regards constitutional bills of rights, the vagueness of the text inevitably invests those responsible for applying such bills with some law making capacity. ${ }^{41}$ This is evident when broadly worded provisions such as the First Amendment of the US Constitution ${ }^{42}$ or article 8 of the $\mathrm{ECHR}^{43}$ are at issue - the range of textually coherent, alternative

${ }^{40}$ That is, some litigants are more likely to win because they satisfy the substantive rules that the legal system has set out - a defendant who sells defectively dangerous goods in a jurisdiction which prohibits such activities is less likely to win the case than the plaintiff, however impartial the judge.

${ }^{41}$ Pace Ronald Dworkin, as in 'No Right Answer?' in P M S Hacker and J Raz (eds.) Law, Morality and Society. Essays in Honour of H L A Hart (Oxford; Clarendon 1977).

42 'Congress shall make no law respecting an establishment of religion, or prohibiting the free exercise thereof; or abridging the freedom of speech, or of the press; or the right of the people peaceably to assemble, and to petition the Government for a redress of grievances.'

43 ' 1 . Everyone has the right to respect for his private and family life, his home and his correspondence. 2 . There shall be no interference by a public authority with the exercise of this right except such as is in accordance with the law and is necessary in a 
outcomes is as wide as the range of factual scenarios arguably implicating those guarantees. If the judge is to produce an outcome, she must make choices which define the legal content of those provisions. ${ }^{44}$

Likewise, to interpret a bill of rights, or any legal document, a judge needs a theory of interpretation. If she had no such theory, she would have no means of recognising the meaningfulness of the texts with which she is presented. ${ }^{45}$ The choice of a theory of interpretation, though one bounded by what is politically possible, will inevitably have some impact on the kind of results she believes the legal texts require. ${ }^{46}$ Consequently, the necessity of choosing a theory of interpretation can be regarded as an investment of law making competence in those responsible for using the law to adjudicate disputes in the name of the jurisdiction. Thus, between the openness of the text and the choices faced by judges in their selection of a theory for its interpretation, the application of a bill of rights requires some judicial creativity. Put differently, to resolve 'rights' questions, judges must make some law. Evidently, judges would find it impossible to make law (however little is necessary) without personal ideas as to what is morally and politically desirable. Thus, as a qualified lawmaker, Justice Scalia is entitled to hold normative views about what the law should be and how it is to be determined. Anyone with such views will find certain legal outcomes, such as the success or failure of Hamdan's petition, more plausible than others. In light of these interpretive realities, as between litigants, an inequality of legal arms is an inevitable feature of constitutional adjudication. Unless we start resolving our lawsuits by rolling dice, we cannot expect our judges to be equally likely to find favour with the contending sides - quite apart from the inequalities of opportunity brought about by the unambiguous substantive content of the legal regime. As such, there is no reason in principle for insisting that judges refrain from making normative statements in their public remarks. ${ }^{47}$

democratic society in the interests of national security, public safety or the economic well-being of the country, for the prevention of disorder or crime, for the protection of health or morals, or for the protection of the rights and freedoms of others.'

${ }^{44}$ The point was well made by John P Frank, 'Disqualification of Judges: In Support of the Bayh Bill' 35 Law and Contemporary Problems 43 (1970) at 48 'Supreme Court Justices are strong-minded men, and on the general subject matters which come before them, they do have propensities; the course of decision cannot be accounted for in any other way.'

${ }^{45}$ For an elaboration of this point see F Schauer 'Precedent and Necessary Externality of Constitutional Norms' 17 Harvard J Public Policy 45, 50-56 (1994).

${ }^{46}$ Different theories of the role of precedent, social science evidence, legislative intent, 'evolving' meaning and foreign law each yield potentially different results when factored into acts of legal reasoning.

${ }^{47}$ Whether conceived as a matter of principle or prudence, the 'appearance of judicial impartiality' involves an objective test. However, it is difficult to base an objective 


\section{SCALIA, HAMDAN AND THE PRINCIPLES OF SUBJECT MATTER RECUSAL}

Similarly, there is no principled basis for criticising judges for articulating their theories of constitutional interpretation, however strongly those bear on the outcome of the particular cases before them. Judges can hardly avoid choosing interpretative theories with which there is less than universal agreement if they are to render justice in accordance with legal prescriptions of any kind.

\section{Section B: The French Connection}

For a system of judicial review for constitutionality, in which the authority to pursue constitutional cases lay exclusively with the organs and officers of the state, we might leave our theoretical analysis there. Such a system prevails in France, ${ }^{48}$ which, for present purposes, we will characterise as a system of 'official' review. ${ }^{49}$ However, in jurisdictions where parties may invoke the constitution to challenge the legality of their circumstances, a different scenario emerges. There can only be contending parties to a constitutional dispute if one side believes that the law operates to protect their interest by frustrating the other's interest and if that side has a right to the operation of constitutional law with regard to his own particular circumstances. By contrast, under a system of official judicial review, the initiating officer or organ has no right to have the disputed provision interpreted with regard to his personal circumstances. This is not for a moment to suggest that the officers in question have no personal interest in the operation of the law or that the operation they advocate would not work to protect their personal interests while frustrating those of another. The process of 'seizing' France's Constitutional Court is entirely political. Crucially, however, an initiating officer has no right to advert to the unconstitutional effect that the law would have on his personal circumstances - political or otherwise - as a reason for grounding the Conseil

finding of partiality on a forthright judicial lecture if we accept that, objectively, judges will have (and need) views on controversial constitutional issues which will affect how they decide the cases which come before them. Even as a principle in itself, therefore, it seems that the appearance of impartiality would not be undercut by overt judicial moralising - impartiality being defined so as to exclude the differential impact such moralities exert on particular cases.

${ }^{48}$ According to article 61 of the French Constitution of 1958, prior to their promulgation, laws may be referred to the Conseil Constitutionnel for review of their constitutionality by the President of the Republic, the Prime Minister, the President of the National Assembly, the President of the Senate, and sixty deputies or sixty senators.

${ }^{49}$ The usual English terminology here is 'abstract' review; this contrasts with the use of 'concrete' review in the common law world. 
Constitutionnel's judicial review. The contending sides to official review act only in the context of their state offices. As such, even though individual national legislators line up on either side of the legal question before the constitutional tribunal, the state, as legislator, is simply carrying out its processes of law making. Neither state itself nor its citizens are parties to a legal dispute.

Whenever they initiate judicial review, French legislators act in their official capacity as such. Through invoking the question of constitutional conformity, those minority parliamentarians who opposed the assembly passage of a bill are not simply engaging in a legal dispute with the ones in majority; both sides are using their constitutionally delegated powers to collectively make law. A constitutional challenge to a bill by an assembly minority is simply a continuation of its lawmaking struggle with the majority. Put differently, legislators invoking judicial review represent elements of the state's law making apparatus, whose cohesion in a bill's route to promulgation is assured by its Constitution. This is not simply the theory; practically speaking, before the Conseil Constitutionnel, no delegation of deputies or head of government pleads how their personal constitutional rights will be compromised by the proposed law. ${ }^{50}$ Conversely, this is the very first thing a litigant will plead in a private constitutional challenge, à l'américaine. In a system of official judicial review, a court applies constitutional law to prospective statutory law having regard to the impact each will have on the circumstances of the nation at large. In a system of 'unofficial' judicial review, the court applies constitutional law to statutory law with regard also to the impact each will have on the circumstances of the individual litigant. ${ }^{51}$ In other words, a qualitatively different paradigm is at work where citizens or other private entities may constitutionally vindicate their personal interests against the state and one another: here we find two sides contesting not simply the constitutionality of a law, but the constitutionality of a law as it relates to them as legal actors. We shall characterise this model as a system of 'adversarial' judicial review.

Having pursued this theoretical excursion we now are in a position to address the question of judicial predispositions towards particular constitutional cases in systems of adversarial review. If a party to a dispute exercises his right to have the constitution operate with regard to his personal circumstances (ie, if he litigates), an adjudicator cannot proceed without knowing the relationship between those circumstances and the constitution. Since a given party will hold the best, and possibly the only, information on

${ }^{50}$ For a selection of recent Conseil Constitutionnel briefs and decisions see http://www.conseil-constitutionnel.fr/divers/actu.htm

${ }^{51}$ In using the term 'apply' here, I do not mean to imply that the courts in either system would fail to engage in some law-making while discharging these functions. 
his own circumstances, it would appear irrational for an adjudication to take place without a party's input. But a party's right to have the constitution operate with regard to his circumstances bears more fundamental implications. ${ }^{52}$ First, that it is inappropriate for an adjudicator to deny a party the opportunity of having the law operate with respect to his circumstances by refusing to listen with an open mind to his account of those circumstances. Thus, in Hamdan, one would expect the members of the US Supreme Court to listen to Hamdan's account of the facts. We have no reason to believe Justice Scalia failed do so. The second implication is that an adjudicator ought to listen with an open mind to a party's account of how the law at issue applies to his circumstances. In the absence of an open mind regarding the application of law to the facts, even full knowledge of a party's account of his circumstances will not allow a judge to discharge his duty in adversarial litigation. So in Hamdan, the fact that Justice Scalia may have possessed full knowledge of Hamdan's presentation of his circumstances did not relieve him of his duty to listen with an open mind to Hamdan's legal arguments. Though the second implied judicial duty does not follow as obviously as the first, it is as much a component of an individualised approach to administering justice. $^{53}$

Keeping an open mind towards a litigant's legal argument is important for the proper administration of justice because it is only by way of their relationship to the law that the pertinence of a party's circumstances becomes manifest. Thus, the 'fact' that an accused party had a confession induced by torture is relevant to his subsequent trial only because it might violate what he

\footnotetext{
${ }^{52}$ To clarify the use of the concept of 'right' in this context: a party has a right to ask a court to apply, say, article 9 of the UK Human Rights Act/ECHR on religious freedom to his circumstances, to wit, that he has been prohibited from wearing a turban in his workplace. Evidently, our prospective litigant could not take such a case were he unable to mention his workplace and religious circumstances. Likewise, in applying article 9, a court could not simply ignore the litigant's claim that he had been prohibited from wearing his turban, assuming the alleged prohibition went to the decisive legal issue(s). In one sense, the 'right' in question is a practical concomitant of the possibility of non official parties participating in litigation. The very point of such participation will be to bring law to bear on the circumstances of the participants. Nevertheless, the concept of right I have in mind is broader than this - it is also a norm of concern for an individualised administration of justice. The right would thus apply outside the realm of purely constitutional adjudication.

${ }^{53}$ In terms of the role which the notion of individuality plays in conceptions of the administration of justice, note its addition to the following formula of judicial impartiality, 'The reason [for the fundamental nature of the right to fair hearing by an impartial tribunal] is obvious. All legal arbiters are bound to apply the law as they understand it to the facts of individual cases as they find them' Locabail (23) at 295 (joint judgment of Bingham LCJ, Woolf MR and Scott V-C).
} 
says is a legal interest in constitutional due process. A party cannot choose which of his many circumstances to present to a court for the purpose of having the law applied thereto without a theory of how the law makes them relevant. A party would not know whether to mention his belief that he was tortured if he did not have a theory that he was entitled to due process and that due process proscribed the use of torture. A party's presentation of his circumstances is thus a product of his theory of how the law makes them relevant - or how it ought to. Consequently, until a court tests a party's legal theory it cannot make much claim to have applied the law specifically to the party's circumstances since it cannot assess the party's presentation of those circumstances. For instance, until Justice Scalia listened to what Hamdan had to say about the Geneva Conventions, he would not be able to understand why the Petitioner mentioned that he was captured 'on the field of battle in a war between the United States and the government of Afghanistan'; both of which, arguably, represented mutual signatories of the Geneva Conventions during the 2001 war against the Taliban's Afghanistan. ${ }^{54}$ If he did not understand why Hamdan mentioned the facts he did, Justice Scalia would have been unable to assess Hamdan's facts on their own terms, know how the presented facts purported to relate to each other, or know what non-presented facts he should ask Hamdan about. Where a judge applies his theory of the law to a litigant's facts (as Scalia did to Hamdan's facts at his Swiss Q\&A) without bothering with the litigant's own theory of why those facts are legally relevant, he cannot claim to have diligently applied the law with regard to the litigant's particular circumstances. This is so because the judge would have failed to investigate the prima facie reason for the party's appearance in his court - that, given his circumstances, the law is on his side.

In short, a party's presentation of his personal circumstances represents the court's primary source of information about them; if an assessment of it is neglected, the court cannot be certain to have satisfied his right to have the constitution operate with regard to his circumstances. Practically speaking, a failure to approach the parties' legal arguments with an open mind would risk leaving a court shooting in the dark with respect to their circumstances. ${ }^{55}$ I

\footnotetext{
${ }^{54}$ Brief for the Petitioner before the US Supreme Court, No 05-184 at 7.

${ }^{55}$ The point here is not that courts invariably follow the legal direction suggested by the parties' arguments or that they should feel reluctant to decide cases sua sponte. Rather, the point is that it would be exceptional, and generally regarded as incorrect, for a court to decide a case sua sponte or otherwise without listening to counsel's argument as to how it should be decided. Having done so, the court is of course free to do whatever it thinks is best. Conversely, 'shooting in the dark' is unproblematic in a system of official review since the court owes no duty to the persons of the initiating officers. The court is at large with respect to how its decisions affect the particular circumstances of its referents, qua referents.
} 


\section{SCALIA, HAMDAN AND THE PRINCIPLES OF SUBJECT MATTER RECUSAL}

should emphasise that this concern regarding extrajudicial commentary does not apply where a judge's thinking - however controversial - is framed in the abstract, without regard to upcoming cases. Rather, our analysis pertains to judicial remarks which set out the law to be applied in a pending case. Such commentary would indicate a close mindedness towards the case's subject matter. Given the implications of such an attitude for the individualised administration of justice in an adversarial system, remarks of that nature warrant a judge's recusal. The distinction between a judge's dispositions in relation to a particular party's prospects and his preferential attitudes to certain moral and policy positions is now readily apparent. Moral preferences in genuinely hypothetical scenarios do not prejudice the realisation of any party's right to the constitutional vindication of his particular circumstances since they do not compromise a judge's ability to appreciate the legal theory explaining a party's presentation of his circumstances. ${ }^{56}$

\section{Section C: The Dissenting Opinion}

The final element of the realist objection to the recognition of a principle of judicial open-mindedness lies in the operation of dissenting opinions. In relation to capital punishment, one US Supreme Court Justice went so far as to declare in a dissent that, "[f]rom this day forward, I no longer shall tinker with the machinery of death." 57 Likewise, Justice Scalia expressed views similar to those he advocated in Switzerland in his dissent in Rasulv Bush. ${ }^{58}$

\footnotetext{
${ }^{56}$ Note that there is no analogy between personal interest bias (at least of a pecuniary nature) and the normative preconceptions affecting judicial approaches to the determination of cases. The latter are an essential element of appellate adjudication, the former are not. Cf Philip Bryden, 'Legal Principles Governing the Disqualification of Judges' 82 Canadian Bar Rev 3 (2003) at 555, 589, 'if we must recognize that our law requires parties to take on faith to some extent the ability of our judges to be open-minded in deciding cases that require them to examine their own views and predispositions, there is a certain irony in our reluctance to require parties to accept the ability of judges to act impartially when relatively insignificant personal interests are at stake.' In truth, there is no conflict between open-mindedness in deciding individual cases and the use of personal normative views in the making of those decisions. If, having listened to a litigant's presentation of their position, a judge makes a choice that is within the ambit of his normative discretion, we might well consider that choice normatively misguided. Having applied his discretion equally to each party's position, we cannot, however, regard the judge as partial. Conversely, one may be as open-minded as Solomon as to whether one's financial interest in the outcome of a case ought to affect that outcome, but one will remain nonetheless a judge in one's own case.

${ }^{57}$ Callins $v$ Collins, 510 US 1141(1994) (Blackmun J dissenting).

${ }^{58}$ Rasul v Bush 542 US 466 (2004).
} 
By allowing minority judges to express their views as to the correct interpretation of the law (notwithstanding the majority's definitive interpretation thereof) while not expecting them to adopt the majority's version in future cases, we are recognising that judges have ideas as to what the law should be and that those ideas will affect how they dispose their future cases. Thus, if we are going to permit judges to publish dissents, how can we coherently hold them to a standard of subject matter impartiality? The first point to note is that if a judge were to extrajudicially articulate an abolitionist platform in apparent reference to a particular capital case he would open himself to the same charge of judicial partiality we have been canvassing in relation to Justice Scalia in Hamdan. In terms of Blackmun's dissent, it is arguable that the judge was not in fact construing the law with regard to particular capital cases but was instead setting out a general philosophy that was open to being countered by a state in any given case. ${ }^{59}$ But either way, it is perfectly possible for a judge to intend his opinion in case A, dissenting or otherwise, to rule his decision in case B, prior to having heard argument in the latter.

In common with majority opinions, dissents are ex cathedra judicial statements. They enjoy a place in the theories of authority adhered to in most adversarial legal systems - certainly that of the United States. How often have we heard approving judicial reference to Murphy's dissent in Korematsu, ${ }^{60}$ Holmes' dissent in Lochner, ${ }^{61}$ Harlan's dissent in Plessy? ${ }^{62}$ In the recent Lawrence $v$ Texas $^{63}$ decision, the Supreme Court overruled its decision of 17 years earlier, Bowers $v$ Hardwick. ${ }^{64}$ In so doing, the Court

${ }^{59}$ See fn 27 , '. . . I believe that the death penalty, as currently administered, is unconstitutional. Perhaps one day this Court will develop procedural rules or verbal formulas that actually will provide consistency, fairness, and reliability in a capital sentencing scheme.'

${ }^{60}$ Korematsu v US 323 US 214 at 233 (1944) (Murphy J dissenting). For Supreme Court majority opinions citing the dissent see for instance Hamdi $v$ Rumsfeld 542 US 507 at 535 (2004); Adarand Constructors, Inc v Pena 515 US 200 at 215 (1995) and City of Richmond v J A. Croson Co 488 US 469 at 501 (1989).

${ }^{61}$ Lochner $v$ New York 198 US 45 at 65 (1905) (Holmes J dissenting). For Supreme Court majority opinion citations see for instance College Sav Bank v Florida Prepaid Postsecondary Education Expense Board 527 US 666 at 691 (1999); Planned Parenthood of Southeastern Pennsylvania v Casey 505 US 833 at 861 (1992) and Rivera $v$ Minnich 483 US 574 at 578 (1987).

${ }^{62}$ Plessy v Ferguson 163 US 537 at 552 (1896) (Harlan J dissenting). For Supreme Court majority opinion citations see for instance Johnson v California 543 US 499 at 513 (2005); Romer v Evans 517 US 620 at 623 (1996) and New York v US 505 US 144 at 185 (1992).

${ }^{63} 539$ US 558 (2003).

${ }^{64} 478$ US 186 (1986). 


\section{SCALIA, HAMDAN AND THE PRINCIPLES OF SUBJECT MATTER RECUSAL}

quoted a passage from Justice Stevens' Bowers dissent and held that "Justice Stevens' analysis, in our view, should have been controlling in Bowers and should control here." It is difficult to imagine the court drawing on a contemporaneous public lecture by Justice Stevens to make the same point. Conversely, it is easy to imagine Justice Scalia's dissent in Rasul being cited in a future Supreme Court decision on the Executive's war powers, whereas there would be no question of considering the citation of his substantively similar comments in Switzerland. None of this is to say that dissenting opinions possess anything remotely like the degree of authority accorded to previous court decisions, simply that they possess some element of judicial authority. In practice, dissents, like majority opinions, are taken to play a part in the doctrine of precedent, which in turn is taken to play a part in the jurisdiction's theory of legal authority. When judges hold forth in their bench opinions they are exercising an authority which the legal system has accorded them. In majority, they are, in part, creating law. In dissent, they are creating intimations of law which lie dormant, perhaps forever, but which both detract from the degree of authority accorded to the original decision ${ }^{65}$ and which facilitate a future judicial change of course. As such, there is no analogy between off bench Q\&A sessions and ex cathedra judicial pronouncements. The latter represent the legal authorities governing future cases (albeit to greatly differing degrees), the former represent the opinions of those who must yet determine, on an ad hoc basis, what the law should be in future cases. Like majority opinions, dissenting opinions take on a systemic identity independent of their authors. Once handed down, their authority would not be overridden by any contrary extrajudicial assertion their authors might make. Consequently, a dissenting opinion, even if intended by its author to apply to another, as yet unargued case, cannot be regarded as prejudicing the litigants of that future case since, once expressed, it is no longer a creature of that author's intent. By definition, litigants seek the justice provided by their legal system's theory of authority, that is, they come to advance their interests by exercising their right to have the constitution applied to their particular circumstances. The judicial operation of that theory of authority - the judicial citation of previous judicial opinions, including dissents - is what litigants have expressed an interest in obtaining. Litigants cannot subsequently criticise the operation of that theory as partial because a judge cites his previous dissent. Such citations represent a working element of the jurisdiction's theory of authority; a theory the parties recognised by litigating on its terms. By contrast, extrajudicial speeches constitute a non-authoritative

\footnotetext{
${ }^{65}$ It is rare for a court to omit the fact that the supporting precedent it is citing was a unanimous opinion. The reason for this is evident - unanimity is deemed to increase, albeit only slightly, the authority of the citation.
} 
vehicle for the expression of normative opinions. As such, when directed at particular cases, the views they disclose may compromise the litigant's prospects for a specific (ie, ad hoc) determination of the law with respect to his individual circumstances.

\section{CONCLUSION}

Questions of subject matter prejudice can be problematic. The maintenance of a consistent approach to such questions - at least those arising from acts of appellate adjudication - will be not realised in the absence of a clearly theorised account of the underlying need for judicial impartiality. In practice, we would be likely to find ourselves criticising the non-recusal decisions of judges whose philosophies we find disagreeable while happily attending the lectures of those whose philosophies we admire. The foregoing analysis suggests that a line may be drawn between a judge's preconceptions concerning controversial matters relevant to a legal dispute before him and any preconception he might have regarding how those matters relate to that dispute. Drawing the line in this fashion would preserve individualised judicial attention to litigants as an element in our theory of the proper administration of justice. Taking this approach would recognise statutory recusal norms such as the US Code's Section 455, or indeed the US Constitution's Fourteenth Amendment, ${ }^{66}$ as coherent markers for judicial propriety within jurisdictions featuring judicial discretion and dissenting opinions. We may thus conclude that Justice Scalia's apparent contravention of these laws in his adjudication of Hamdan's petition was an action which may not be excused on the 'realist' ground that, whatever the doctrinal position, appellate judges will inevitably have normative preconceptions going into any dispute.

A question deserving of further consideration is the precise role of 'the appearance of justice.' The notion is widely employed as a test for recusal, and can be understood either as a normative end in itself ${ }^{67}$ or as a method of ensuring that as few as possible actually partial judgments occur. ${ }^{68}$ Perhaps the best characterisation of the 'appearance of justice' in the former role would be that the reasonable person has a right to be confident that her jurisdiction's legal system operates impartially - in addition to any right to be

\footnotetext{
${ }^{66}$ As interpreted in Re Murchison (n 25).

${ }^{67}$ A plausible interpretation of Hewart LCJ's famous dictum that it 'is of fundamental importance that justice should not only be done but should manifestly and undoubtedly be seen to be done.' R. v Sussex Justices, ex parte McCarthy [1924] 1 K.B. 256 at 259.

${ }^{68}$ See Ebner (n 23) para 7.
} 
subject to a legal system which operates impartially. However, given what we can expect the reasonable person to acknowledge regarding the quasi legislative nature of adjudication, it is unclear how abstract extrajudicial commentary could shake her confidence in judicial impartiality - even where the commentary concerns itself with controversial questions. ${ }^{69}$ Thus in practice, at least as regards subject matter prejudice, whether 'reasonable appearance' is recognised as an independent principle rather than simply an indispensable instrument for eliminating substantive partiality might not make very much difference.

${ }^{69}$ Recall that we are merely addressing the issue of judicial impartiality; a perfectly impartial judge might use his discretion to bring immoral or misguided philosophies to bear on the cases before him. 